\title{
Silver Sagebrush Community Associations in Southeastern Alberta, Canada
}

\author{
Paul F. Jones, ${ }^{1}$ Roy Penniket, ${ }^{2}$ Livio Fent, ${ }^{3}$ \\ Joel Nicholson, ${ }^{4}$ and Barry Adams ${ }^{5}$ \\ Authors are ${ }^{1}$ Wildlife Biologist, Alberta Conservation Association, 530 8th St S, Lethbridge, Canada T1J 2J8; \\ ${ }^{2}$ President, Penniket \& Associates Ltd, PO Box 329, Granum, Canada T0L 1A0; \\ ${ }^{3}$ Manager, GIS Operations Data Stores, Resource Data Branch, Alberta Sustainable Resource Development (ASRD), \\ Public Lands Division, 9820 106th St, 14th Fl, Edmonton, Canada T5K 2J6; \\ ${ }^{4}$ Nongame Biologist, ASRD, Fish and Wildlife Division, 346 3rd St SE, Medicine Hat, Canada T1A 0G7; and \\ ${ }^{5}$ Range Management Specialist, ASRD, Public Lands Division 100, 5401 1st Ave S, Lethbridge, Canada T1J 4 V6.
}

\begin{abstract}
Greater sage-grouse (Centrocercus urophasianus) habitat in southeastern Alberta is limited by the distribution of silver sagebrush (Artemisia cana Pursh). We conducted a landscape assessment of silver sagebrush throughout the current range of sage-grouse in southeastern Alberta. Black-and-white aerial photography acquired in the fall of 2001 was used to map silver sagebrush. Contact print stereo pairs were interpreted using a stereoscope and initially classified into 1 of 13 site classes based on soil type and landscape feature (e.g., recent agriculture). Each site polygon was further broken down into smaller polygons based on the percentage of silver sagebrush occupancy, density distribution, and height. A total of 4626 site polygons were identified and classed into 1 of 13 site classes. To ensure all assumptions of statistical tests were met, the data set was reduced to 9 site classes. The mean percentage of silver sagebrush occupancy was significantly different between the 9 site classes $(F=285.00, \mathrm{df}=8$, $P<0.001)$. The lotic site class had the highest mean percentage of occupancy, followed by overflow and old cultivated site classes. The frequencies of density distribution were not equal for all site classes (Pearson's chi-square $=5727.09, \mathrm{df}=72$, $P<0.001)$. Lotic had greater than expected occurrences in distribution classes 8 through 12 whereas overflow had greater than expected occurrences in distribution classes 8 and 10. The frequencies of height class were not equal for all site classes (Pearson's chi-square $=4382.15, \mathrm{df}=24, P<0.001)$. Lotic and overflow sites had greater than expected occurrences in the mixed and tall height classes, whereas blowouts, loamy and saline lowlands had greater occurrences in the small height class. Understanding the occupancy, density distribution, and height of silver sagebrush across the landscape will assist in understanding the resource selection patterns and management of sage-grouse in Alberta, Canada.
\end{abstract}

\section{Resumen}

En el sudeste de Alberta, el hábitat del "greater sage-grouse" (Centrocercus urophasianus) esta limitado por la distribución del "silver sagebrush" (Artemisia cana Pursh). Condujimos una evaluación del paisaje del "silver sagebrush" en todos los lugares del rango actual del "Sage-grouse" en el sudeste de Alberta. Para mapear el "silver sagebrush" se utilizaron fotografías aéreas en blanco y negro adquiridas en otoño del 2001. Pares de fotografías se interpretaron usando un esteroscopio e inicialmente clasificadas dentro de 1 a 13 clases de sitios basados en el tipo de suelo y propiedades del paisaje (por ejemplo, agricultura reciente). Posteriormente, cada polígono de los sitios se dividió en polígonos mas pequeños basados en el porcentaje de ocupación, distribución de la densidad, y altura del "silver sagebrush." Un total de 4626 polígonos se identificaron y clasificaron en 1 de las 13 clases de sitio. Para asegurar se cumplieran todos los supuestos de las pruebas estadísticas, el conjunto de datos se redujo a 9 clases de sitio. La media del porcentaje de ocupación del "silver sagebrush" fue significativamente diferente entre las 9 clases de sitio. $(F=285.00, \mathrm{gl}=8, P<0.001)$. La clase de sitio lotic tuvo el mayor promedio de porcentaje de ocupación, seguido por la clases de sitio derrame y áreas de cultivo viejas. Las frecuencias de la distribución de la densidad no fueron iguales para todas las clases de sitio (chi cuadrada de Pearson $=5727.09 \mathrm{gl}=72, P<0.001$ ). El sitio lotic tuvo mayores ocurrencias que las esperadas en las clases de distribución 8 al 12 mientras que en el sitio de derrame lo tuvo en las clases del 8 al 10. Las frecuencias de clases de altura no fueron iguales para todos las clases de sitio (chi cuadrada de Pearson $=4382.15, \mathrm{gl}=24$, $P<0.001)$. Los sitios lotic y derrame tuvieron ocurrencias mayores a las esperadas en las clases mixtas y altas, mientras que los sitios de vientos y tierras bajas salinas y franco tuvieron mayores ocurrencias en las clases de altura pequeña. Entender la ocupación, distribución de la densidad, y altura del "silver sagebrush" a través del paisaje ayudará a entender los patrones de selección del recurso y manejo del sage-grouse en Alberta, Canadá.

Key Words: distribution, greater sage-grouse, height, occupancy, site

Research was funded in part by Government of Canada Habitat Stewardship Program for Species at Risk, Alberta Conservation Association, and Alberta Sustainable Resource Development.

Correspondence: Paul F. Jones, Alberta Conservation Association, 530 8th St S, Lethbridge, Alberta, Canada T1J 2J8. Email: paul.jones@gov.ab.ca

Manuscript received 19 July 2003; manuscript accepted 23 April 2004. 


\section{INTRODUCTION}

Within Canada, greater sage-grouse (Centrocercus urophasianus) occur only in southwestern Saskatchewan and southeastern Alberta. The population of sage-grouse in Canada has declined an estimated $66 \%-92 \%$ over the past 30 years (Aldridge 2000 ). The associated contraction of the sage-grouse range has also been extreme, decreasing to about $4000 \mathrm{~km}^{2}$ from the historical estimate of $49000 \mathrm{~km}^{2}$. Sage-grouse habitat in southeastern Alberta is limited by the distribution of sagebrush (Artemisia spp.) (Aldridge 2000; Canadian Sage Grouse Recovery Team 2001). To date, mapping of the current distribution and community associations of sagebrush has not occurred.

The ecology of silver sagebrush (Artemisia cana Pursh) in Canada is not well understood. Silver sagebrush is a freebranching, erect shrub that has a deep tap root system, as well as a rhizome system that produces vegetative sprouts (Walton 1984; Adams et al. 2004). In the Northern Great Plains, silver sagebrush occurs on mesic sites that consist of productive, deep, fertile soils with the potential for considerable forage production (White and Currie 1983). Silver sagebrush has been shown to positively respond in terms of ground cover and forage production to increased precipitation levels in Montana (Branson and Miller 1981).

Fent (1999) evaluated different solar angles and aerial films to determine if silver sagebrush could be mapped from relatively small-scale (1:20 000) aerial photography. The study showed that high-resolution film, in conjunction with a relatively low sun angle $\left(20^{\circ}\right)$, provided the best results for detecting sagebrush distribution and density (Fent 1999). This methodology was the basis for our landscape assessment of silver sagebrush in southeastern Alberta. The objective of this study was to determine the relationships between site class, based on soil type and landscape feature (e.g., recent cultivation), and specific silver sagebrush attributes (occupancy, density distribution, and height class). Understanding these relationships will facilitate the management of silver sagebrush and sage-grouse in Alberta.

\section{MATERIALS AND METHODS}

\section{Project Area}

The study area covered townships 1 , range 1 (lat $49.00^{\circ} \mathrm{N}$, long $\left.110.0^{\circ} \mathrm{W}\right)$ through township 6 , range $7\left(49.52^{\circ} \mathrm{N}, 110.95^{\circ} \mathrm{W}\right)$ west of the 4th meridian for a total of 42 townships (408 999 ha) in southeastern Alberta. This area encompasses the core area of the sage-grouse habitat. The majority of the terrain is gently rolling with watercourses dissecting the landscape. Elevations range from a low in the Milk River floodplain at the 49th Parallel of $830 \mathrm{~m}$ to $1262 \mathrm{~m}$ along the north-central project edge in township 6 range 4. The main aspect is south facing toward the Milk River drainage with the river cutting through the southwest corner. The breaks along the Milk River are steep and rough with little vegetation. The southwestern corner has a north aspect towards the channel of the Milk River. There are several tributaries flowing from the north to the southeast. At the time of the project (fall and winter of 2001), these streams and the Milk River were suffering from an extended drought with very little water present. Water occurrences were confined to a few scattered dugouts and reservoirs. The drought had a significant negative effect on vegetation vigor.

\section{Photo Acquisition}

A slightly modified version of the Fent (1999) recommendation was used for this project. Flying was initiated in the first week of October 2001 and completed by 7 November 2001. Sun angles were set between $20^{\circ}$ and $25^{\circ}$ above the horizon, restricting the photo acquisition to the early morning or early evening period. Photos were taken at a scale of 1:15 000. The flying altitude ranged from $3200 \mathrm{~m}$ to $3261 \mathrm{~m}$ above sea level or approximately $2286 \mathrm{~m}$ above the ground surface. A Zeiss Jena LMK metric camera equipped with forward motion compensation and a 152-mm focal length lens was used to take the photos. Photo lines were taken with a $60 \%$ forward-exposure overlap and a $20 \%$ lateral-exposure overlap providing good stereo pair coverage. The film used was AgfaPhoto's Aviphot Pan 80. This film provided the high resolution (101 line pairs per millimeter) required for detecting sagebrush conditions at a scale of 1:15 000 and also met the average gradient processing condition $(G=1.75)$ needed to enhance the relatively low ground brightness range over the study area. The negatives were printed on $0.23 \mathrm{~m} \times 0.23 \mathrm{~m}$ contact prints (1 548 prints) using grade 4 contrast paper to further enhance the scene contrast and aid the interpreter in discerning textural detail. A field inspection of random sites within the study area was conducted during photo acquisition and immediately after photo processing to aid the interpreter in classifying the photos.

\section{Photo Interpretation}

A digital ortho image covering the study area was acquired from local counties (Cypress County and County of Fortymile). The digital images were plotted at a scale of 1:15 000 and combined with digital planimetric data (transportation, hydrology, township and section lines), ground-truthed data, and vegetation plot locations. Agricultural Region of Alberta Soil Inventory Database (AGRASID) soil classification lines (Alberta Soil Information Centre 2001) with the township boundary were plotted on a Mylar film overlay at the same scale as the ortho image plots. The ortho plot and the corresponding Mylar were aligned and taped together (one pair) to maintain spatial integrity. Twentyone plots were produced to cover the project area. Each plot covered 2 townships.

Contact print stereo pairs were interpreted using a mirror stereoscope equipped with 3 power magnifying binoculars. Site class polygons were interpreted and outlined on each evennumbered photo using an omnichrome pencil. Site classes were based on soil type and landscape formation (Table 1), which were developed to address variations in the study area. Each site polygon was further broken down into smaller polygons based on the percentage of silver sagebrush occupancy, the density distribution, and the height. The percentage of occupancy is an estimate of the area of the polygon covered with sagebrush plants and is not a definition of the crown closure of the plants that is used in forestry applications. Based on the shadow effect created by the low sun angle, crown closure could not be determined. Twelve density distribution classes defined the abundance and scatter of sagebrush plants in each polygon (Table 2) (Adams et al. 2003). We added a 13 th class (class 0 ) for analysis purposes 
Table 1. Site class definitions used in classifying silver sagebrush communities in southeastern Alberta, Canada, 2001.

\begin{tabular}{|c|c|c|}
\hline $\begin{array}{l}\text { Site class } \\
\text { Number }\end{array}$ & $\begin{array}{l}\text { Site class } \\
\text { label }\end{array}$ & Definition \\
\hline Class 1 & Lotic & $\begin{array}{l}\text { Stream floodplains and channels } \\
\text { consisting of lowlands with significant } \\
\text { sage brush growth }\end{array}$ \\
\hline Class 2 & Overflow & $\begin{array}{l}\text { Fluvial fans, aprons, and lower slopes } \\
\text { off plateaus varying from low, flat } \\
\text { benches above the stream banks to } \\
\text { gently rolling, lower slopes }\end{array}$ \\
\hline Class 3 & Blowouts & $\begin{array}{l}\text { Soil types with blown patches creating } \\
\text { a mottled response in the photography }\end{array}$ \\
\hline Class 4 & Loamy & Uplands, plateau tops, and plains. \\
\hline Class 5 & $\begin{array}{l}\text { Saline } \\
\text { lowlands }\end{array}$ & $\begin{array}{l}\text { Low, depression areas receiving more } \\
\text { than normal moisture, with salt or } \\
\text { alkali accumulations and very limited } \\
\text { vegetation growth }\end{array}$ \\
\hline Class 6 & Other & $\begin{array}{l}\text { Escarpments, sand dunes, badlands. } \\
\text { These sites are very rough or } \\
\text { unproductive soils for vegetation } \\
\text { of most types }\end{array}$ \\
\hline Class 7 & Mixed brush & $\begin{array}{l}\text { Northern areas and some stream } \\
\text { channels usually containing higher } \\
\text { moisture levels. This site class is } \\
\text { separated out by the biophysical } \\
\text { conditions of vegetation and moisture }\end{array}$ \\
\hline Class 8 & $\begin{array}{l}\text { Recently } \\
\text { cultivated }\end{array}$ & $\begin{array}{l}\text { Recent activity or disturbance. These sites } \\
\text { are currently being farmed or cropped } \\
\text { for grain or forage. }\end{array}$ \\
\hline Class 9 & Old cultivated & $\begin{array}{l}\text { These sites have been cultivated at some } \\
\text { time in the past and have either } \\
\text { been reseeded or undisturbed for a } \\
\text { period of time. }\end{array}$ \\
\hline Class 10 & Urban & $\begin{array}{l}\text { Development sites by human activity, } \\
\text { towns, oil batteries, and farmyards. }\end{array}$ \\
\hline Class 11 & Fires & $\begin{array}{l}\text { Recent occurrences of fires in } \\
1999,2000 \text {, and } 2001 .\end{array}$ \\
\hline Class 12 & Poplar & $\begin{array}{l}\text { Predominantly poplar in the river } \\
\text { systems (Milk River and tributaries). }\end{array}$ \\
\hline Class 13 & Water & $\begin{array}{l}\text { Lakes, rivers, streams, and water } \\
\text { developments }\end{array}$ \\
\hline
\end{tabular}

that represented no sagebrush present. Density distribution is not a measure of individual plants per unit area but a description of the distribution of plants within a polygon (e.g., rare, single clump, or continuous dense occurrence of plants).

The height of the sagebrush was difficult to determine in the aerial photography. Lighting and contrast in the photography affected the length of the shadow and the texture of the brush response. Trends in height were a qualitative observation and defined to some degree by the terrain, site class, and field observations. Considering these factors, caution was exercised when interpreting the height results. Height class was defined as none, short $(<0.5 \mathrm{~m})$, tall $(>0.5 \mathrm{~m})$, or mixed. Interpreted data was checked with ground-truth data to assist in verifying classification accuracy.
Table 2. Density distribution descriptions used in the silver sagebrush classification project, southeastern Alberta, Canada, 2001.

\begin{tabular}{|c|c|c|}
\hline Class & Description of abundance in polygon & Distribution \\
\hline 1 & Rare & \\
\hline 2 & A few sporadically occurring individual plants & $\bullet \quad . \bullet$ \\
\hline 3 & A single patch & 88 \\
\hline 4 & A single patch plus a few sporadically occurring plants & $\infty \quad$ \\
\hline 5 & Several sporadically occurring plants & $\bullet \bullet \bullet$ \\
\hline 6 & A single patch plus several sporadically occurring plants & 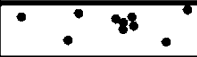 \\
\hline 7 & A few patches & क $\quad .8^{\infty}$ \\
\hline 8 & A few patches plus several sporadically occurring plants & \\
\hline 9 & Several well spaced patches & 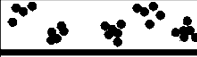 \\
\hline 10 & Continuous uniform occurrences of well spaced plants & \\
\hline 11 & $\begin{array}{l}\text { Continuous occurrence of plants with a few gaps } \\
\text { in the distribution }\end{array}$ & \\
\hline 12 & Continuous dense occurrence of plants & \\
\hline
\end{tabular}

\section{Statistical Analysis}

We examined silver sagebrush characteristics (percentage of occupancy, density distribution, and height) based on site classification. A 1-way analysis of variance (ANOVA) was used to test whether there was a significant difference in the mean percentage of sagebrush occupancy among the different sites. If a significant difference was detected, the Tukey test was employed to calculate the multiple comparisons between means (Zar 1984). We tested the hypotheses that the frequencies of density distribution and height were the same for all sites using the chi-square statistic and a contingency table (Zar 1984). We adhered to the assumptions of the chi-square test that no expected values are $<1$ and that no more than $20 \%$ of the expected values are $<5$ (Neu et al. 1974; Zar 1984). If these were violated, we opted to remove rows (site class) and/or columns (distribution or height class) to ensure the assumptions were met (Zar 1984). If a significant result occurred, we used the Bonferroni $z$ statistic to determine which occurrences were greater than expected for each site class (Neu et al. 1974). All tests were performed using SPSS (2001) except for the Bonferroni $z$ statistics, which were performed using the MS Excel (Microsoft Corporation 1997) spreadsheet.

\section{RESULTS}

A total of 4626 site polygons were identified and categorized into 1 of 13 classes (Table 3). The loamy site class covered the greatest area, followed by blowouts, overflow, and other. The poplar and fire site classes covered the least area. Water covered $3 \%$ of the study area. Mean polygon size ranged from 9.05 ha (urban) to 215.64 ha (recent cultivation).

The initial test that the frequencies of density distribution were the same for all sites resulted in the violation of the 2 assumptions for the chi-square statistic. To overcome these violations, we set a minimum value of 50 observations for either row or column total. This resulted in the removal of site classes 
Table 3. Number of polygons and area for the 13 site classes for the silver sagebrush classification project, southeastern Alberta, Canada, 2001.

\begin{tabular}{lrrrrr}
\hline & & & & \multicolumn{2}{c}{ Mean } \\
Site class & $\begin{array}{c}\text { Total } \\
\text { area (ha) }\end{array}$ & \% Area & $\begin{array}{c}\text { Number of } \\
\text { polygons }\end{array}$ & $\begin{array}{r}\text { polygon } \\
\text { size (ha) }\end{array}$ & \multicolumn{1}{c}{ SE } \\
\hline Lotic & 23327 & $6 \%$ & 426 & 54.76 & 3.39 \\
Overflow & 57001 & $14 \%$ & 884 & 64.48 & 4.54 \\
Blowouts & 88780 & $22 \%$ & 594 & 149.46 & 11.27 \\
Loamy & 111055 & $28 \%$ & 532 & 208.75 & 18.71 \\
Saline lowlands & 2511 & $1 \%$ & 60 & 41.85 & 5.78 \\
Other & 54360 & $14 \%$ & 255 & 213.18 & 34.29 \\
Mixed brush & 2739 & $1 \%$ & 38 & 72.07 & 13.74 \\
Recently cultivated & 28895 & $7 \%$ & 134 & 215.64 & 66.03 \\
Old cultivated & 15881 & $4 \%$ & 446 & 35.61 & 3.93 \\
Urban & 1068 & $0.3 \%$ & 118 & 9.05 & 1.12 \\
Fires & 583 & $0.1 \%$ & 22 & 26.48 & 6.35 \\
Poplar & 776 & $0.2 \%$ & 43 & 18.05 & 2.63 \\
Water & 11790 & $3 \%$ & 1074 & 10.98 & 3.26 \\
Total & 398765 & $100 \%$ & 4626 & 86.20 & 4.09 \\
\hline
\end{tabular}

7 (mixed brush), 11 (fires), and 12 (poplar). We also removed site class 13 (water) because it had no sagebrush characteristics. These sites were also removed from the analysis for mean percentage of occupancy and sagebrush height to ensure consistency. Density distribution classes 7 and 9 were also removed because of their low sample sizes.

The mean percentage of silver sagebrush occupancy was significantly different between the remaining 9 site classes $(F=285.00, \mathrm{df}=8, P<0.001)$ (Table 4$)$. The lotic site had the highest mean percentage of occupancy, followed by overflow and old cultivated sites (Table 4). Recent cultivated sites and urban land had no silver sagebrush occupancy (Table 4).

For the density distribution analysis, we had a 9 row (site) $\times 10$ column (density distribution class) contingency table with a total of 3422 observations. The frequencies of density distribution were not equal for all site classes (Pearson's

Table 4. Mean percentage of shrub occupancy for 9 site classes for the silver sagebrush classification project, southeastern Alberta, Canada, 2001.

\begin{tabular}{lccccc}
\hline Site class & $\begin{array}{c}\text { No. of } \\
\text { Polygons }\end{array}$ & Mean & SE & Minimum & Maximum \\
\hline Lotic & 426 & $45.87^{\mathrm{a}}$ & 1.38 & 0 & 100 \\
Overflow & 884 & $19.51^{\mathrm{b}}$ & 0.63 & 1 & 100 \\
Blowouts & 594 & $9.29^{\mathrm{c}}$ & 0.29 & 1 & 50 \\
Loamy & 532 & $3.30^{\mathrm{d}}$ & 0.12 & 1 & 25 \\
Saline lowlands & 60 & $3.18^{\mathrm{c}, \mathrm{d}, \mathrm{e}}$ & 0.85 & 1 & 50 \\
Other & 255 & $9.37^{\mathrm{c}, \mathrm{e}}$ & 0.79 & 0 & 80 \\
Recently cultivated & 134 & $0.00^{\mathrm{d}, \mathrm{e}}$ & 0.00 & 0 & 0 \\
Old cultivated & 446 & $16.88^{\mathrm{b}}$ & 0.89 & 1 & 90 \\
Urban & 118 & $0.00^{\mathrm{d}, \mathrm{e}}$ & 0.00 & 0 & 0 \\
Total & 3449 & 15.71 & 0.35 & 0 & 100 \\
\hline
\end{tabular}

${ }^{a-e}$ Means with the same superscripted number are not significantly different at the $P=0.05$ level based on the Tukey test. For example, the mean for Overflow is not significantly different from the mean for Old cultivated.

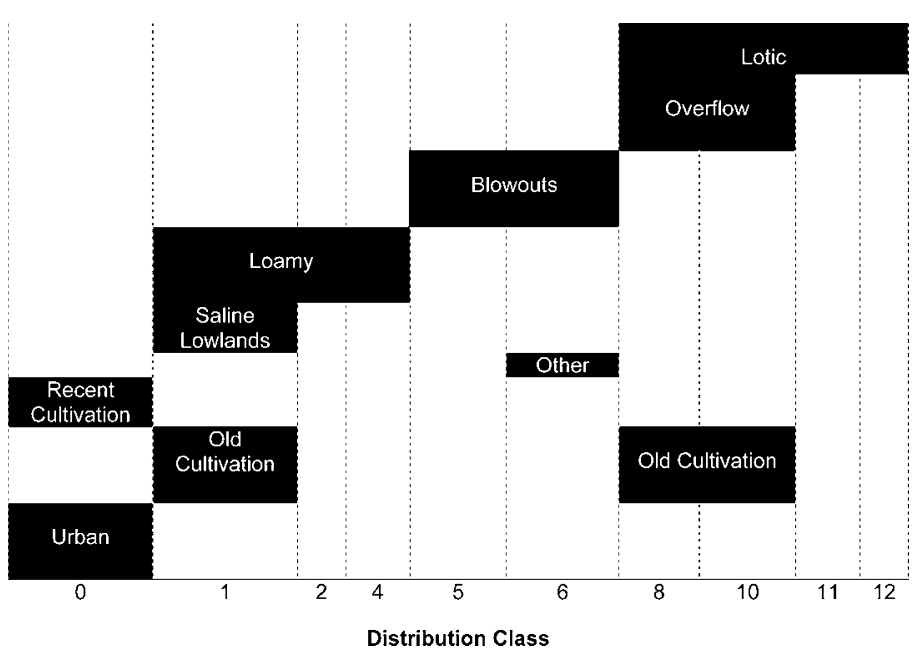

Figure 1. Greater-than-expected frequencies of sagebrush density distribution for 10 site classes in southeastern, Alberta, Canada, 2001.

chi-square $=5727.09, \mathrm{df}=72, P<0.001)$. Figure 1 depicts the results of the Bonferroni $z$ statistics in which greater-thanexpected frequencies occurred. All other cases are either less than expected or equal occurrences. Lotic had greater than expected occurrences in distribution classes 8-12 whereas overflow had greater-than-expected occurrences in distribution classes 8 and 10. Recent cultivation and urban sites had greater occurrences in class 0 .

For the height analysis, we had a 9 row ( site $) \times 4$ column (height) contingency table with a total of 3448 observations. The frequencies of height class are not equal for all site classes (Pearson's chi-square $=4382.15, \mathrm{df}=24, P<0.001$ ). Figure 2 depicts the results of the Bonferroni $z$ statistics in which greater-than-expected frequencies occurred. All other cases are either less than expected or equal occurrences. Lotic and

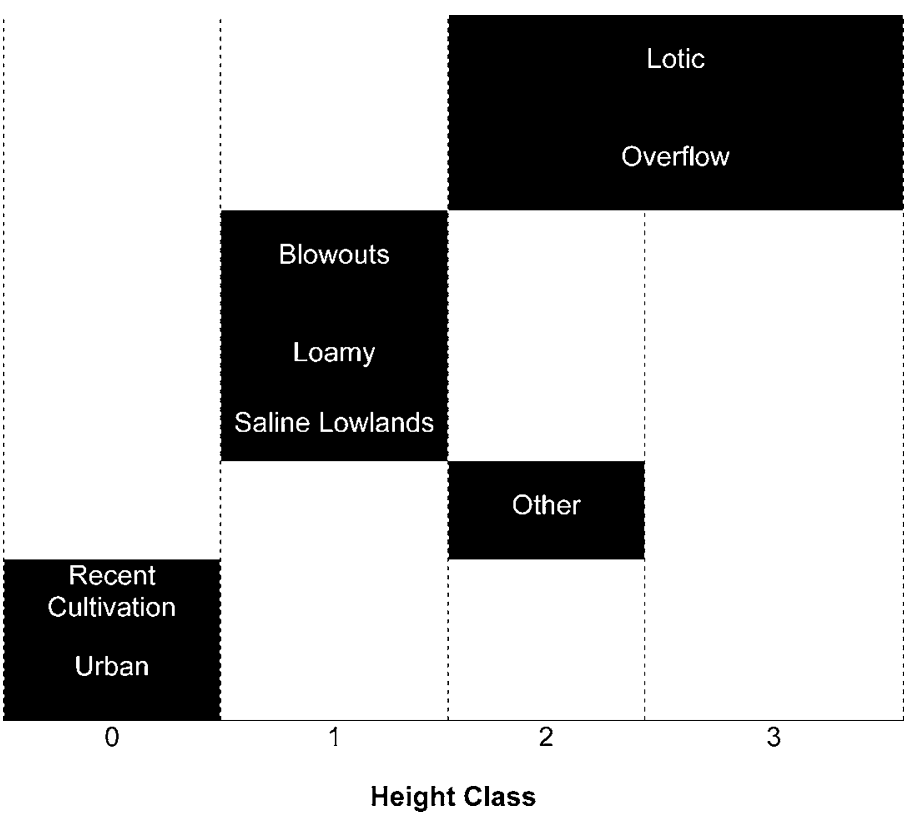

Figure 2. Greater-than-expected frequencies of sagebrush height classes for 8 site classes in southeastern, Alberta, Canada, 2001. 
overflow sites had greater-than-expected occurrences in the mixed and tall height classes whereas blowouts, loamy and saline lowlands had greater occurrences in the small height class.

\section{DISCUSSION}

The purpose of this research was to determine the distribution, density, and height of silver sagebrush to facilitate the conservation of sagebrush habitat and sage-grouse. The specific objective was to determine the relationships between silver sagebrush attributes (percentage of occurrence, density distribution, and height) and site condition (soil type and landscape feature).

\section{Silver Sagebrush Characteristics}

Studies reported in the literature indicate that silver sagebrush is associated with mesic sites with productive fertile soils (White and Currie 1983; McNeil and Sawyer 2001). McNeil and Sawyer (2001) reported silver sagebrush occupying overflow sites consisting of alluvial fans, aprons, and terraces of broad poorly drained swales to glacial melt water channels. These overflow sites tend to have episodic runoff events resulting in areas with greater moisture and sediment levels than welldrained upland sites under the dry, mixed grass, climatic conditions (McNeil and Sawyer 2001). Both sodicity and sediment deposition create favorable conditions for silver sagebrush (McNeil 1996; Adams et al. 2004). Thompson and Hansen (2002) describe the silver sagebrush-western wheatgrass (Agropyron smithii Rydb.) association as a dry riparian type.

Our results supported the notion that silver sagebrush is a quasi-riparian species, requiring mesic sites. Within the study area, the lotic and overflow sites were the driest of the riparian classes. The lotic sites have juvenile regosolic soils, whereas the overflow sites were more-developed brown chernozems. These 2 sites had the best sagebrush characteristics (i.e., greater mean percentage of occupancy, denser, more even distribution, and taller plants). The other end of the spectrum would be the loamy site, which occurs on the uplands, plateau tops, and plains. These sites were the most xeric of all sites and had low occupancy, sparse distribution, and small sagebrush plants.

An interesting phenomenon was the sagebrush characteristics for the old cultivated sites. This site class had the thirdhighest mean percentage of occupancy and occurred with greater-than-expected frequency in distribution classes 8 and 10 (medium and high density classes). This indicates the ability of silver sagebrush to colonize sites following a period of disturbance. Further investigation is required to determine the age of these sites to assess how quickly silver sagebrush can colonize disturbed sites.

Further investigation into the response of silver sagebrush to disturbance is possible by monitoring the areas classed as fire. Silver sagebrush is fairly resistant to fire and will resprout vigorously following a fire event (Aldridge and Brigham 2002). White and Currie (1983) stated that burning of silver sagebrush under favorable spring moisture conditions resulted in low plants kill rates and vigorous sprouting with brush cover returning to original, preburn conditions quickly. Our study classed 22 polygons ( $583 \mathrm{ha}$ ) as fire, with the events occurring between 1999 and 2001. These polygons had no sagebrush attributes at the time of photo interpretation. Monitoring is required to determine the response of silver sagebrush to the fire events. This assessment will allow managers to determine the feasibility of fire as a management tool to promote sagebrush regeneration and enhance habitat for sage-grouse.

Our approach to mapping silver sagebrush distribution across the landscape involved a hierarchal approach of first determining the site class, based on soil type and landscape formation, and then classifying silver sagebrush attributes within the determined site class. The approach provided the level of detail that was required for mapping silver sagebrush at a landscape level. That said, a few improvements could be made. First, the assessment of plant height is subjective as the interpreter is interpreting shadow length and not actual plant height. This required us to use broad height categories of small, mixed, and tall. A more accurate assessment of plant height could be achieved by using softcopy photogrammetry technology. We used the technology for a few test plots, estimating the height of the plants, which were then field validated. Our estimates were within $5 \mathrm{~cm}$ of actual plant height. The mixed brush site class was required as a number of areas, primarily in the northern portion of the study area and along some stream channels where higher moisture levels persisted, the interpreter had difficulty differentiating between silver sagebrush, thorny buffalo berry (Shepherdia argentea Nutt.), common wild rose (Rosa woodsii Lindl.), and silver-berry (Elaeagnus commutata Bernh.). The degree to which silver sagebrush composes these areas is unknown. Ground-truthing would assist in breaking the silver sagebrush component out of these polygons.

\section{MANAGEMENT IMPLICATIONS}

Management of habitat for prairie grouse, e.g., sage-grouse and sharp-tailed grouse (Tympanuchus phasianellus), has been shown to be an effective management strategy (Schroeder and Baydack 2001). Determining the location and quality of the sagebrush habitat is the first step in developing management strategies for sage-grouse recovery. Connelly et al. (2000) recommended that all states and provinces with sage-grouse, document the amount and condition of sagebrush. Our study has determined the extent and distribution of silver sagebrush in southeastern Alberta.

Sage-grouse are a sagebrush-obligate species found yearround within the range of sagebrush (Braun et al. 1977; Connelly et al. 2000). The Canadian population is associated year-round within the range of silver sagebrush (Aldridge 2000; Aldridge and Brigham 2003). Sagebrush has been identified as an important component for nest and brood-rearing success in sage-grouse (Connelly et al. 1991; Gregg et al. 1994; Sveum et al. 1998; Aldridge and Brigham 2002). In our study area, Aldridge and Brigham (2002) determined that sage-grouse selected nest sites that were under sagebrush plants that were taller and provided greater canopy cover than other available habitat. Similar conditions were selected for brood-rearing habitat, where hens with broods selected dense tall sagebrush sites (Aldridge and Brigham 2002). They concluded that sagebrush habitat is limited in southeastern Alberta, Canada (Aldridge and Brigham 2002). Our results suggest that this may be the case. From a landscape perspective, the site class that would best meet the needs of sage-grouse, based on the 
site-selection results of Aldridge and Brigham (2002), would be the lotic sites. The lotic sites had the greatest mean shrub occupancy $(45.87 \%)$, dense plant distribution (classes 8, 10, 11 , and 12), and taller plants (height classes 2 and 3) but only occupied $6 \%$ of the study area. The next site class that would best satisfy the habitat requirements of sage-grouse would be the overflow class, which had a dense distribution (classes 8 and 10 ) and tall plants (height class 2 and 3), but it had significantly less mean shrub occupancy $(19.51 \%)$. Including the area classed as overflow with the lotic sites would increase the area of suitable habitat to $20 \%$ of the study area, still suggesting that sagebrush habitat is limited.

Sage-grouse research in Alberta has been focused at one level, namely the selection of nesting and brood-rearing sites (Aldridge 2000; Aldridge and Brigham 2002). Determination of habitat selection patterns by sage-grouse at coarser scales has not been possible because of a lack of data. Our results will facilitate the determination of selection patterns by sage-grouse at more than one level. Examination as to whether the nesting and broodrearing locations determined by Aldridge and Brigham (2002) are located within the lotic and overflow sites will further determine their need for conservation and protection.

\section{ACKNOWLEDGMENTS}

Authors wish to thank Cam Aldridge (University of Alberta) for supplying vegetation data, Kelley Kissner (Alberta Fish and Wildlife Division) for suggestions and assistance with data analysis, and Lana Robinson (Alberta Resource Data Division) for providing base data. We thank 2 anonymous reviewers, G. L. Anderson, and M. K. Owens for their helpful comments on the manuscript.

\section{LITERATURE CITED}

Adams, B. W., G. Ehlert, C. Stone, M. Alexander, D. Lawrence, M. Willoughby, D. Moisey, C. Hincz, And A. Bogen. 2003. Range health assessment for grassland, forest and tame pasture. Edmonton, Alberta, Canada: Public Lands and Forests Division, Alberta Sustainable Resource Development. Publication T/044. $105 \mathrm{p}$.

Adams, B. W., J. Carlson, D. Milner, T. Hood, B. Cairns, and P. Herzog. 2004. Beneficial grazing management practices for sage grouse (Centrocercus urophasianus) and ecology of silver sagebrush (Artemisia cana) in southeastern Alberta. Lethbridge, Alberta, Canada: Public Lands and Forests Division, Alberta Sustainable Resource Development. Publication T /049. 52 p.

Alberta Soll Information Centre. 2001. Agrasid 3.0: Agricultural Region of Alberta Soil Inventory Database (Version 3.0). Available at: http://www1. agric.gov.ab.ca/soils/soils.nsf. Accessed 2 August 2001.
AldRidge, C. L. 2000. Reproduction and habitat use by sage grouse (Centrocercus urophasianus) in a northern fringe population [thesis]. Regina, Saskatchewan, Canada: University of Regina. $109 \mathrm{p}$.

Aldridge, C. L., And R. M. Brigham. 2002. Sage-grouse nesting and brood habitat use in southern Canada. Journal of Wildlife Management 66:433-444.

Aldridge, C. L., And R. M. Brigham. 2003. Distribution, abundance, and status of the Greater Sage-Grouse, Centrocercus urophasianus, in Canada. The Canadian Field-Naturalist 117:25-34.

Branson, F. A., and R. F. Miller. 1981. Effects of increased precipitation and grazing management on northeastern Montana rangelands. Journal of Range Management 34:3-10.

Braun, C. E., T. Britt, and R. O. Wallestad. 1977. Guidelines for maintenance of sage grouse habitats. Wildlife Society Bulletin 5:99-106.

Canadian Sage Grouse Recovery Team. 2001. Canadian sage grouse recovery strategy. Edmonton, Alberta, Canada: Alberta Sustainable Resource Development and Saskatchewan Environment and Resource Management. $55 \mathrm{p}$.

Connelly, J. W., W. L. Wakkinen, A. D. Apa, And K. P. Reese. 1991. Sage grouse use of nest sites in southeastern Idaho. Journal of Wildlife Management 55: 521-524.

Connelly, J. W., M.A. Schroeder, A.R. Sands, and C.E. Braun. 2000. Guidelines to manage sage grouse populations and their habitats. Wildlife Society Bulletin 28:967-985.

Fent, L. 1999. Aerial films and solar angles: Influences on silver sagebrush inventory. Journal of Range Management 52:32-38.

Gregg, M. A., J. A. Crawford, M. S. Drut, and A. K. Delong. 1994. Vegetation cover and predation of sage grouse nests in Oregon. Journal of Wildlife Management 58:162-166.

McNelL, R. L. 1996. Landscape evolution and surficial geology of the Pakowki Basin, Alberta. Lethbridge, Alberta: Pedology Services Ltd. 14 p.

McNelL, R. L., AND B. J. SAWYER. 2001. Soils and landscapes associated with silver sagebrush and sage grouse. Lethbridge, Alberta, Canada: Landwise Inc. 36 p.

Microsoft Excel [Computer Program]. 1997. Version SR-2. Redmond, WA: Microsoft Corporation.

Neu, C. W., C. R. Byers, and J. M. Peek. 1974. A technique for analysis of utilization-availability data. Journal of Wildlife Management 38:541-545.

SPSS [COMPUTER PRogram]. 2001. Base 11.0. Chicago, IL: SPSS Inc. 574 p.

Schroeder, M. A., and R. K. Baydack. 2001. Predation and the management of prairie grouse. Wildlife Society Bulletin 29:24-32.

Sveum, C. M., M. D. Edge, And J. A. Crawford. 1998. Nesting habitat selection by sage grouse in south-central Washington. Journal of Range Management 51:265-269.

Thompson, W. H., and P. L. Hansen. 2002. Classification and management of riparian and wetland sites of the Alberta Grassland Natural Region and adjacent subregions. Corvallis, MT: Bitterroot Restoration Inc. $416 \mathrm{p}$.

Walton, T. P. 1984. Reproductive mechanisms of plains silver sagebrush Artemisia cana cana in southeastern Montana [thesis]. Bozeman, MT: Montana State University. $161 \mathrm{p}$.

White, R. S., ANd P. O. CurRie. 1983. The effects of prescribed burning on silver Sagebrush. Journal of Range Management 36:611-613.

ZaR, J. H. 1984. Biostatistical analysis. Upper Saddle River, NJ: Prentice Hall. $718 \mathrm{p}$. 